\title{
PENINGKATAN KUALITAS AIR SUMUR BOR SEBAGAI UPAYA MEMENUHI KEBUTUHAN AIR MINUM WARGA KOTA SORONG
}

\author{
Nur Hidayah Annas \\ Program Study Teknik Sipil Universitas Muhammadiyah Sorong \\ Jalan Pendidikan No 27 Kota Sorong, Propinsi Papua Barat \\ Email : nurhidayahannassipil@gmail.com
}

\begin{abstract}
ABSTRAK
Air merupakan senyawa kimia yang sangat penting bagi kehidupan mahkluk hidup di bumi. Fungsi air bagi kehidupan tidak dapat digantikan oleh senyawa lain. Penggunaan air yang utama dan sangat penting bagi kehidupan adalah sebagai air minum, namun demikian air dapat menjadi sangat berbahaya bila mana tidak tersedia dalam kondisi yang benar. Mengingat pentingnya peran air, sangat diperlukan adanya sumber air yang dapat menyediakan air yang baik dari segi kuantitas dan kualitasnya. Kualitas air yang digunakan sebagai air minum sebaiknya memenuhi persyaratan secara fisik, kimia, dan mikrobiologi. Dalam rangka memenuhi kebutuhan air minum maka dilakukan peningkatan kualitas air sumur bor menjadi air layak minum dengan metode fitrasi denga zeolite adan karbon aktif.
\end{abstract}

KATA KUNCI : kota sorong, air bersih, peningktan kualias 


\section{PENDAHULUAN}

\section{Latar Belakang}

Kota Sorong adalah adalah sebuah kota di Provinsi Papua Barat Indonesia, yang mempunyai luas wilayah mencapai $1.105,00 \mathrm{~km} 2$ atau sekitar $1.13 \%$ dari total luas wilayah Papua Barat. Wilayah kota ini berada pada diketinggian 3 meter dari permukaan laut dan suhu udara minimum di Kota Sorong sekitar $23,1^{\circ} \mathrm{C}$ dan suhu udar maksimum sekitar $33,7^{\circ} \mathrm{C}$, curah hujan tercatat $2,911 \mathrm{~mm}$, curah hujan cukup merata sepanjang tahun.

Air merupakan senyawa kimia yang sangat penting bagi kehidupan mahkluk hidup di bumi. Fungsi air bagi kehidupan tidak dapat digantikan oleh senyawa lain. Penggunaan air yang utama dan sangat penting bagi kehidupan adalah sebagai air minum, namun demikian air dapat menjadi sangat berbahaya bila mana tidak tersedia dalam kondisi yang benar. Mengingat pentingnya peran air, sangat diperlukan adanya sumber air yang dapat menyediakan air yang baik dari segi kuantitas dan kualitasnya (Nasrudin Purwonugroho, 2013).

Kualitas air yang digunakan sebagai air minum sebaiknya memenuhi persyaratan secara fisik, kimia, dan mikrobiologi. Syarat fisik air tidak berwarna, temperatur normal, rasanya tawar, tidak berbau, jernih dan tidak mengandung zat padatan. Syarat kimia air dalam $\mathrm{pH}$ netral, tidak mengandung bahan kimia beracun, tidak mengandung garam atau ion-ion logam, kesadahan rendah dan tidak mengandung bahan organik. Syarat mikrobiologi tidak mengandung bakteri patogen dan nonpatogen (Nasrudin Purwonugroho, 2013).

\section{Tujuan Penelitian}

1. Untuk meningkatan kualitas air sumur bor sebagai upaya memenuhi kebutuhan air minum warga kota sorong

\section{STATE OF THE ART}

Adapun penelitian terdahulu yang terkait dengan penelitian ini adalah sebagai berikut :

\section{Nasrudin Purwonugroho (2013)}

Nasrudin, dari Univeritas Muhammadiyah Surakarta Tahun 2013 dalam penelitiannya tentang "Keefektifan Kombinasi Media Filter Zeolit Dan Karbon Aktif Dalam Menurunkan Kadar Besi (Fe) Dan Mangan (Mn) Pada Air Sumur". Berdasarkan hasil penelitian dapat disimpulkan sebagai berikut :

a. Kombinasi media filter zeolit dan karbon aktif efektif dalam menurunkan kadar Fe dan Mn pada air sumur.

b. Kadar Fe dan Mn sebelum dilakukan perlakuan yaitu 2,910 mg/l dan 0,900 mg/l.

c. Kadar Fe dan Mn setelah dilakukan perlakuan dengan media filter zeolit rata-rata sebesar 0,160 mg/l dan $0,137 \mathrm{mg} / \mathrm{l}$, dengan media filter karbon aktif rata-rata kadar Fe 0,217 mg/l dan kadar Mn ratarata $0,247 \mathrm{mg} / \mathrm{l}$, dan menggunakan media filter zeolit dengan karbon aktif rata-rata kadar $\mathrm{Fe} 0,183$ $\mathrm{mg} / \mathrm{l}$ dan kadar Mn rata-rata $0,203 \mathrm{mg} / \mathrm{l}$.

d. Kombinasi media filter yang paling efektif menurunkan kadar Fe dan Mn adalah kombinasi media filter zeolit dengan keefektifan sebesar $94,50 \%$ dan $84,78 \%$.

\section{Rusdiana, Danang Biyatmoko, Gt. Chairuddin, Azidi Irwan}

Rusdiana, Danang Biyatmoko, Gt. Chairuddin, Azidi Irwan "Optimasi Peningkatan Kualitas Air Sumur Gali Menjadi Bahan Baku Air Minum Dengan Menggunakan Kombinasi Zeolit Dan Kapur Tohor" Dari uraian hasil penelitian di atas dapat disimpulkan beberapa hal sebagai berikut :

a. - Perlakuan kombinasi zeolit dan kapur tohor tidak berpengaruh nyata menurunkan kadar Fe, Mn, Escherichia coli, kekeruhan, warna air sumur gali, akan tetapi sangat nyata meningkatkan $\mathrm{pH}$ air sumur gali $(\mathrm{p}<0.01)$.

- Kelompok pengambilan sampel berpengaruh nyata memperbaiki semua parameter kualitas air sumur gali yang diukur, termasuk bau dan rasa.

b. Kombinasi zeolit dan kapur tohor terbaik adalah kombinasi Z1K2 yang mampu meningkatkan kualitas untuk parameter besi $0,228 \mathrm{mg} / \mathrm{l}$, mangan $0,136 \mathrm{mg} / \mathrm{l}$, dan kekeruhan $5 \mathrm{NTU}$, kemudian perlakuan Z2K2 yang mampu memperbaiki kualitas parameter fisika warna 51,50 TCU, parameter bau dan rasa 2,55 (agak berbau dan agak berasa), dan meningkatkan $\mathrm{pH}$ dengan nilai 7,953, dan perlakuan Z2K1 mampu menurunkan Escherichia coli 14,33 jumlah per $100 \mathrm{ml}$ sampel. 


\section{Hardini, I, Karnaningroem, $\mathbf{N}$}

Hardini, I, Karnaningroem, N meneliti tentang " Peningkatan Kualitas Air Sumur Gali Menjadi Air Bersih Menggunakan Filter Mangan Zeolit Dan Karbon Aktif : Studi Kasus Air Sumur Gali Permukiman Desa Banjar Po Sidoarjo". Dari penelitian yang telah dilakukan pada filter karbon aktif, filter mangan zeolit, dan filter seri karbon aktif dan mangan zeolit terhadap sumur gali adalah sebagai berikut :

a. Efisiensi removal konsentrasi besi $(\mathrm{Fe})$, mangan $(\mathrm{Mn})$, dan zat organik $(\mathrm{KMnO} 4)$ dalam air sumur gali dengan masing - masing menggunakan filter karbon aktif, filter mangan zeolit, dan filter seri karbon aktif dan mangan zeolit, paling besar yang terjadi pada ketebalan media $40 \mathrm{~cm}$ dan konsentrasi terbesar, adalah sebagai berikut :

- Efisiensi removal untuk $\mathrm{Fe}, \mathrm{Mn}$, dan $\mathrm{KMnO} 4$ yang terjadi pada filter media karbon aktif yaitu sebesar: efisiensi removal untuk Fe mencapai 73,6\%, Mn 53,33\%, dan KMnO4 70,11\%.

- Efisiensi removal untuk $\mathrm{Fe}, \mathrm{Mn}$, dan $\mathrm{KMnO} 4$ yang terjadi pada filter media mangan zeolite yaitu sebesar: efisiensi removal untuk Fe mencapai 93,52\%, Mn 97,14\%, dan $\mathrm{KMnO} 4$ 40,12\%.

- Efisiensi removal untuk $\mathrm{Fe}, \mathrm{Mn}$, dan $\mathrm{KMnO} 4$ yang terjadi pada filter seri media karbon aktif dan media mangan zeolit yaitu sebesar: efisiensi removal untuk Fe mencapai 93,52\%, Mn 97,14\%, dan $\mathrm{KMnO} 436,0 \%$.

b. Semakin tebal media maka efisiensi penyisihan semakin tinggi. Dalam penelitian ini ketebalan media 40 $\mathrm{cm}$ memiliki efisiensi penyisihan yang lebih tinggi dibanding ketebalan $25 \mathrm{~cm}$. Berikut adalah nilai konsentrasi terbesar yang dapat diturunkan oleh media filter dengan ketebalan $40 \mathrm{~cm}$ :

- Pada filter karbon aktif, konsentrasi Fe turun menjadi 0,793 mg/L, Mn turun menjadi 1,167 mg/L, dan $\mathrm{KMnO} 4$ turun menjadi $17,380 \mathrm{Mg} / \mathrm{L}$.

- Pada filter mangan zeolit, konsentrasi Fe turun menjadi 0,195 mg/L, Mn turun menjadi 0,071 mg/L, dan $\mathrm{KMnO} 4$ turun menjadi $31,6 \mathrm{mg} / \mathrm{L}$.

- Pada filter seri karbon aktif dan mangan zeolit, konsentrasi Fe turun menjadi 0,052 mg/L, Mn turun menjadi $0,048 \mathrm{mg} / \mathrm{L}$, dan $\mathrm{KMnO} 4$ turun menjadi $12,125 \mathrm{mg} / \mathrm{L}$.

c. Semakin tinggi konsentrasi, maka ketebalan media perlu ditambah. Menambah ketebalan media mangan zeolit untuk Fe dan Mn berkadar tinggi, sedangkan media karbon aktif ditambahkan jika kadar KMnO4 yang tinggi.

d. Nilai penurunan penyisihan yang berbeda - beda antara media serta efisiensi penyisihan yang mencapai 95\% hingga 100\% menunjukkan terjadinya Breakthrough pada media.

\section{METODE}

\section{Tahapan Penelitian}

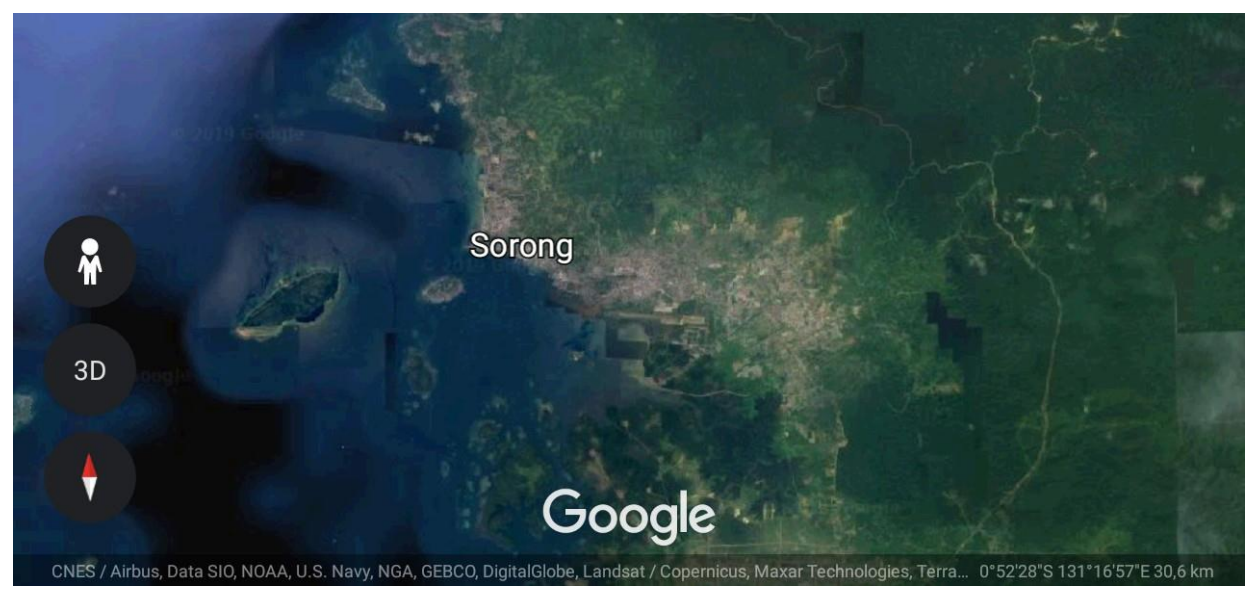

Tahapan penelitian yang digunakan adalah sebagai berikut :

Sampel pada penelitian ini diambil dari sumur bor. Jumlah sampel yang diperlukan pada penelitian ini sebanyak 100 liter. Setiap perlakuan membutuhkan 5 liter air, di mana hasil perlakuan diambil sebanyak 1 liter dengan ditampung di botol aqua untuk pemeriksaan sifat fisik dan kimia yang dilakukan di tempat penelitian. 
Menyiapkan alat dan bahan, seperti media filter zeolit dan karbon aktif yang sudah dicuci dan dikeringkan, kemudian dimasukkan ke bak filter dengan kombinasi media filter zeolit $(60 \mathrm{~cm})$, karbon aktif $(60 \mathrm{~cm})$ dan zeolit $(30 \mathrm{~cm})$ dengan karbon aktif $(30 \mathrm{~cm})$ serta dilakukan replikasi sebanyak 3 kali, kemudian air sampel dimasukkan ke bak filter dengan masing-masing bak diisi 5 liter dan dikontakkan media filter selama 5 menit, kemudian kran outlet dibuka dan air yang keluar ditampung pada botol aqua dan ari hasil filtrasi dimasukkan ke bak penampung sesuai kombinasi media pada masing-masing replikasi. Setelah proses filtrasi selesai air hasil filtrasi diambil masing-masing $1000 \mathrm{ml}$ dan dimasukkan ke dalam botol aqua untuk dilakukan pemeriksaan.

Semua metode penulisan dan analisa dalam artikel ilmiah ini merujuk pada panduan penulisan tugas akhir Fakultas Teknik Universitas Muhammadiyah Sorong tahun 2014 (Pristianto, Amri, \& Rusdi, 2014).

\section{REFERENSI}

1. Nasrudin Purwonugroho (2013). Keefektifan Kombinasi Media Filter Zeolit Dan Karbon Aktif Dalam Menurunkan Kadar Besi (Fe) Dan Mangan (Mn) Pada Air Sumur. Program Studi Kesehatan Masyarakat, Fakultas Ilmu Kesehatan, Universitas Muhammadiyah Surakarta

2. Hardini, I dan Karnaningroem, N. Peningkatan Kualitas Air Sumur Gali Menjadi Air Bersih Menggunakan Filter Mangan Zeolit Dan Karbon Aktif : Studi Kasus Air Sumur Gali Permukiman Desa Banjar Po Sidoarjo. Mahasiswi Jurusan Teknik Lingkungan, FTSP - ITS Surabaya.

3. Rusdiana, Danang Biyatmoko, Gt. Chairuddin, Azidi Irwan. Optimasi Peningkatan Kualitas Air Sumur Gali Menjadi Bahan Baku Air Minum Dengan Menggunakan Kombinasi Zeolit Dan Kapur Tohor. Program Studi Pengelolaan Sumber Daya Alam, Fakultas Perikanan Universitas Lambung Mangkurat, Fakultas MIPA Universitas Lambung Mangkurat.

4. Nur Afdaliah (2018). Analisa Kualitas Air Sumur Bor Warga Kota Sorong. Program Studi Teknik Sipi, Fakltas Teknik, Universitas Muhammadiyah Sorong.

5. Pristianto, H., Amri, I., \& Rusdi, A. (2014, May 9). Pedoman Penulisan Tugas Akhir Fakultas Teknik Universitas Muhammadiyah Sorong 2014. http://doi.org/10.17605/OSF.IO/4VTJM. 